$50 \mid 2019$

Animals in the religion and culture of the Tibetan

Plateau

\title{
On the moral standing of animals in Tibetan Buddhism
}

Au sujet du sens moral des animaux dans le bouddhisme tibétain

\section{Geoffrey Barstow}

\section{(2) OpenEdition \\ Journals}

Electronic version

URL: https://journals.openedition.org/emscat/3865

DOI: $10.4000 /$ emscat.3865

ISSN: 2101-0013

\section{Publisher}

Centre d'Etudes Mongoles \& Sibériennes / École Pratique des Hautes Études

Electronic reference

Geoffrey Barstow, "On the moral standing of animals in Tibetan Buddhism", Études mongoles et sibériennes, centrasiatiques et tibétaines [Online], 50 | 2019, Online since 04 March 2019, connection on 13 July 2021. URL: http://journals.openedition.org/emscat/3865 ; DOI: https://doi.org/10.4000/ emscat.3865

This text was automatically generated on 13 July 2021.

(c) Tous droits réservés 


\title{
On the moral standing of animals in Tibetan Buddhism
}

\author{
Au sujet du sens moral des animaux dans le bouddhisme tibétain
}

\author{
Geoffrey Barstow
}

1 Like other forms of Buddhism, the Tibetan tradition recognizes that animals, like humans, are sentient beings capable of emotions and some level of thought. As such, there is no question that animals are capable of suffering and that humans should consider their needs when making ethical decisions. The question I seek to address in this article, therefore, is not whether Tibetan Buddhism grants animals moral standing at all. Rather, as Bronwyn Finnigan has pointed out in her recent analysis of Buddhist approaches to animal ethics, "The pertinent question [...] concerns how much significance [animals] should have and what this practically entails" (Finnigan 2017, p.3). For while the Tibetan tradition is clear that animals are sentient beings, and therefore share a fundamental similarity with humans, the tradition is also clear that they are less intelligent and capable than humans. This lack of intelligence means that animals are assumed to be incapable of practising religion, meaning that they are incapable of alleviating their suffering on anything more than a temporary, worldly level. Nevertheless, despite their stupidity relative to humans, the Tibetan tradition also makes clear that animals have rich inner lives. They feel physical pain, of course, but also emotions such as fear, love, and desire. As such, I argue that the Tibetan traditions suggests that animals experience the world in ways that are fundamentally similar to the way humans experience the world. Based on this perceived similarity between animal and human mental lives, I argue, Tibetans consistently accorded animals significant moral standing. This view of animals' moral standing is reflected not only in theoretical texts but also in a wide variety of practices aimed at reducing animal suffering ${ }^{1}$.

2 This is not a new question in Buddhist studies. For more than a century, scholars have attempted to understand Buddhism's approach to animals and humanity's responsibility towards them ${ }^{2}$. The frequency of these scholarly analyses suggests that Buddhism has something to offer to contemporary discussions of the status of animals 
vis-à-vis humans, potentially as a counter-weight to the Judaeo-Christian tradition that tends to dominate these debates ${ }^{3}$. For the most part, however, these studies of animals and Buddhism focus on the South Asian Buddhist tradition and often seek to define a pan-Buddhist approach to animals. Fortunately, this trend has begun to change, and important recent scholarship has offered granular analysis of animal ethics in contemporary Sri Lankan Buddhism (Stewart 2015) and in early Chinese Buddhism (Pu Chengzhong 2014), highlighting the degree to which individual Buddhist cultures can approach this question quite differently. Within the study of Tibetan Buddhism in particular, there has also been a recent increase in scholarly attention to the question of animals, as the articles in this issue amply demonstrate. While there has certainly been scholarly attention paid to the question of animal ethics in Tibet, however, I am unaware of previous attempts to specifically look at Tibetan conceptions of the moral standing of animals ${ }^{4}$. By asking how the Tibetan Buddhist tradition has viewed the moral standing of animals relative to that of humans, this article seeks to offer a modest contribution to these larger discussions of Buddhist approaches to animals and animal ethics.

\section{A few definitions}

3 The title of this paper promises a look at the "moral standing of animals in Tibetan Buddhism". None of the terms used in this title are straightforward, however, so before progressing it seems prudent to discuss them. Most significant is the term "moral standing", (sometimes referred to as "moral status" or "moral considerability"). Speaking broadly, moral standing refers to whether or not a particular entity needs to be considered when decisions are being made. To what extend does a particular human actor, in other words, need to consider the impact of their actions on another entity, be that another human, an animal, a tree, or a rock. To give a somewhat trite example, most people would agree that I should consider the impact of my actions on someone else before I decide to punch them. On the other hand, many of those same people would agree that I do not need to consider a rock's feelings before kicking it. The human has moral standing, while the rock does not.

4 In the context of animals, my use of this term refers to the degree to which animals are understood to have moral claims on humans. Human beings interact with animals all the time, and those interactions almost always come from a position where humans have power over animals. If animals have high moral standing in a given society or cultural context, we might expect humans to take the animal's perspective into consideration when they wield that power. Conversely, if animals have little or no moral standing, we might expect humans to disregard the animals' own needs and do whatever they like for any reason. My goal with this article, therefore, is to analyse Tibetan Buddhist attitudes towards animals to try and discern to what degree humans should take animal needs and perspectives into consideration when deciding on a course of action.

5 There are numerous reasons why an animal might have moral standing in a given society. Here, I am primarily interested in what can be called "direct" moral standing. For an animal to have direct moral standing, it needs to have moral standing for its own sake. This is perhaps best understood by contrasting direct moral standing with "prudential" moral standing, in which a human should treat an animal kindly, but only 
because that kindness is good for the human ${ }^{6}$. To give a Buddhist example, a person who only refuses to hurt animals because doing so will increase his or her own store of good karma is granting the animal prudential moral standing. On the other hand, a human who is genuinely concerned with the good of the animal itself grants the animal direct moral standing. While some scholars have suggested that Buddhists only give animals moral standing for prudential reasons, I will argue throughout this article that - at least in the Tibetan tradition - Buddhism grants animals direct moral standing.

Before moving on, I also want to note that moral standing is a concept that, as far as I am aware, does not exist within the Tibetan philosophical tradition. In this article, therefore, I am trying to fit Tibetan ideas about animals into a foreign conceptual framework. It is not surprising that this is a somewhat awkward fit at times, but I hope that the results are useful nonetheless.

7 Following this discussion of moral standing, the next term to consider here is "animal". In formal usage, the English word animal refers to all members of the kingdom Animalia, including humans, other mammals, insects, fish, and so on, but excluding plants and rocks. In order to emphasize that humans are also animals, some scholars have chosen to use the term "non-human animal" to refer to non-human animals. While I am sympathetic to the goals of this rhetorical move, however, I find this term awkward and unwieldy, particularly when the term appears as often as it does in this article. Throughout this article, therefore, I will follow a more colloquial usage in which the term animal refers only to non-human animals.

8 To my knowledge, there is no single Tibetan term that perfectly corresponds to the English word animal. That said, there are several common Tibetan terms that are regularly used to refer broadly to non-human members of the animal kingdom. Perhaps the most common is "düdro" (dud'gro). Düdro literally means "one who goes bent over", thereby suggesting that animals are those who walk on all fours, in contradistinction to humans' bipedal movement. Given its emphasis on four-legged movement, this term is sometimes used in a way that excludes non-quadruped animals such as birds (bya), fish (nya), and insects ('bu srin). In practical usage, however, the term düdro often refers to all non-human animals, and is, therefore, arguably the closest Tibetan term to the common usage of the English word "animal". Even more slippery are "sokchak" (srog chags) and "semchen" (sems can). Sokchak literally means "one who has (or, perhaps, desires) life" and semchen literally means "one who possesses a mind". Strictly speaking, therefore, both terms refer to all animals, including humans. Much like the English "animal", however, both terms are commonly used to refer to all sentient beings except humans. With the exception of a discussion of "semchen", this article will not dwell on the etymologies or specific usages of these terms. It is worth noting at the outset, however, that Tibetan terms for animals are at least as complex as their English counterparts.

9 Finally, a word on what I mean when I speak of "Tibetan Buddhism". This article approaches the Tibetan Buddhist tradition as if it were a monolithic entity. This is obviously an oversimplification. There are a wide variety of religious lineages and viewpoints within the broader Tibetan tradition. Further, there are significant differences in how Tibetans understood Buddhism, depending on what time period we are talking about. Speaking of a single broad tradition, as I do in this article, is both deceptive and unfair to the tradition itself. Given the limited space available, however, it is necessary in an article of this scope. Further, while the Tibetan tradition is quite 
diverse, its approach to animals has remained remarkably (and perhaps surprisingly) consistent over time. In this article I draw on sources from a variety of lineages and time periods (though alert readers may notice a bias towards $18^{\text {th }}$ and $19^{\text {th }}$ century authors from Eastern Tibet), and the views that they present are quite homogenous. Given this consistency and the need to keep this article to a manageable length, I have chosen to speak of Tibetan Buddhism as if it were a unified tradition, despite the fact that this will, inevitably, elide important differences within the tradition.

\section{Alike}

Classical Buddhist cosmologies divide the world into six (sometimes five) different realms: that of gods, demi-gods, humans, animals, ghosts, and denizens of the various hells. Each of these various realms is characterized by certain qualities and experiences. Life as a god, for instance, is characterized in part by the enjoyment of pleasant food and drink. Ghosts, on the other hand, are said to be unable to sate their hunger, and they spend their lives continually seeking out food of any type. Importantly, however, no one is bound forever to a particular form. When an individual born as a ghost eventually dies, their consciousness will be re-born. This subsequent life could be as a ghost again, but it could also be as a god, a human, or any other form of sentient life. Following that life, the consciousness will again be re-born, in a neverending cycle of birth, death, re-birth, and re-death. As this cycle continues, each individual consciousness proceeds through a myriad of different forms of life. While any given consciousness will eventually experience life in each of the different realms, the birth it takes on any particular occasion is governed by its karma. That is, the actions, habits, and tendencies that an individual carries with them at the moment of death are largely - if not quite exclusively - responsible for the type of birth they take in the next life. Thus, someone who is overwhelmingly stingy in one life is likely to be born as a ghost in the next, where their cravings will remain unsatisfied.

11 This six realm cosmology is found in numerous classical Indian Buddhist sources, and was adopted by Tibetan thinkers soon after the introduction of Buddhism. Gampopa's $12^{\text {th }}$ century Jewel Ornament of Liberation, to give one early example, presents a detailed account of this cosmology, including depictions of the various realms and the types of karma required to be born in each. "Greed", Gampopa informs us "has three types of result. The ripened result is to be born as a hungry ghost. The corresponding result is that even if you achieve a human birth, your mind will be based on greed. The dominant result is to be born in a place with poor quality food" (Gampopa 1989, pp. 94-957). In this cosmological vision, particular tendencies - in this example, greed lead to birth in particular realms. Alternative cosmologies can be found in some Tibetan texts and traditions, but for the most part Tibetan Buddhists followed their Indian predecessors and understood the world to be divided into six realms, with an individual's placement determined by their karma.

This cosmology carries with it a number of implications for how the relationship between humans and animals is understood ${ }^{8}$. Most importantly, it suggests that while humans and animals belong to distinct realms of existence, they are not fundamentally different types of beings, and the boundary between their realms is not fixed or impassable. Given the appropriate karma, someone currently born as a human can be re-born as an animal in their next life, and vice versa. The difference between humans 
and animals is not inherent, but merely adventitious, reflecting the karma of that particular moment rather than a core identity. In fact, given that the chain of births is essentially infinite, Buddhists have concluded that not only could an individual be reborn as an animal, they have certainly lived as an animal many times in the past. Someone may be a human now, but that is a temporary situation. They were an animal in the past, and will be again at some point in the future. The human/animal distinction is essentially fluid, depending on the temporary situation rather than a fundamental identity. This understanding is reflected in the fact that both humans and animals are included within the category of semchen (sems can), "sentient beings". Along with gods and ghosts, humans and animals are alike in being sentient, capable of thought. It is the presence of a mind, in fact, that is the only factor unifying beings across all six realms. Since they have a mind, humans, animals, gods, and so on are all fundamentally the same type of being, akin to each other but categorically distinct from insentient objects like plants and rocks ${ }^{9}$.

Since animals are sentient, they suffer in ways reminiscent of humans and other sentient beings. Buddhism famously claims that life is suffused by suffering, and suggests that this suffering can only be fully relieved by pursuing the Buddhist path. As the 18th century teacher Jigmé Lingpa puts it in his Treasury of Precious Qualities, "Understand suffering in this way: whether high or low, there is nowhere in all the six realms that is not subject to pain, change, and the all-pervasive [suffering] of conditioned existence" (Jigmé Lingpa 1985a, p. $20^{10}$ ). Beings born in all six realms, in this view, are subject to the same three basic forms of suffering. While all sentient beings suffer in these basic ways, however, they do so to different degrees and with different emphases. And animals have a particularly heavy burden. The $20^{\text {th }}$ century scholar Dungkar Losang Trinlé explains the suffering experienced by domestic animals in his Doxography of Buddhist Systems, "Some domestic animals, having been enslaved by people, are given burdens they cannot bear, must plough [the fields], and are ridden, etc., whatever [their owners] desire they do. Some animals are killed for the sake of their meat, skin, horns, etc. They have no control over their lives" (Dungkar Losang Trinlé 2004, p. 202 ${ }^{11}$ ). Nor is animal suffering limited to domestic animals. Wild animals may live free and in the wild, but they live in constant fear of each other. As Patrül Rinpoché explains in his famed Words of My Perfect Teacher, "Deer and other wild animals that share our human world experience nothing but fear. They cannot eat a mouthful of food without fear. They prey on each other, and then there are hunters, carnivores and so many other killers. Hawks kill birds and birds kill bugs. Nothing but constantly killing each other" (Patrül Rinpoché 2009, p. 115 $5^{12}$ ). For both domestic and wild animals, life is characterized by physical and mental suffering.

This understanding of animal suffering is brought to life in a striking passage from The Autobiography of Jigmé Lingpa. In this passage, Jigmé Lingpa is critiquing the slaughter of animals for their meat, and uses the animal's experience of the slaughter process as a vivid argument against slaughter:

Having now become animals, your fathers, mothers, siblings and friends from previous lives tremble with fear in the butcher's sinful hands, tears streaming from their eyes, and panting for breath. In that state they wonder what to do. Alas, there is no refuge! There is nowhere to go! Thinking that, right now in this place, they may be killed, their urgent suffering is great. In such a state, like one approaching a terrifying pit of hell-fire, their body is turned upside down, their muzzle is tied up, and their eyes move wildly with lights shining forth. What they see is their stomach 
being opened up. With their feet perpendicular, they are set on the path to the next

life without even a quiver. (Jigmé Lingpa 1985b, pp. 125-126 ${ }^{13}$ ) practice known as "giving the gift of fearlessness" (mi 'jigs pa spyin pa). In this practice, a wealthy individual sets aside some land and declares that hunting (or otherwise harassing animals) is forbidden ${ }^{16}$. Doing so saves animal lives, but it also does something more: it gives the animals that live on this land the ability to live without fear of human hunters. The practice of giving animals the gift of fearlessness reinforces the idea that animals are, in fact, capable of emotions such as fear. It also makes clear, however, that Tibetans understood animals to be capable of differentiating between a situation in which fear is appropriate and one in which it is not. Further, for this practice to have the intended effect, the animals in question have to be capable of not only understanding that there is no hunter at present, but also that there will be no hunter in the future. The Tibetans that promoted and implemented this practice, therefore, must have viewed animals as both emotionally complex (capable of fear) and capable of some level of rational thought (knowing when fear is appropriate and when it is not).

It might be possible to suggest that the state of fearlessness is merely the result of conditioning, meaning that rather than understanding the animals to be consciously aware of the absence of hunters, these authors may simply think the animals gradually become used to not needing to fear humans. But I have found no suggestion in Tibetan literature that the animals are becoming conditioned in this way. Admittedly, texts that mention the gift of fearlessness do not enumerate the exact mechanism fearlessness is achieved. In his recent discussion of sealing, however, however, Carl Yamamoto points to one early reference to the practice, in which humans and animals are both included within the purview of the seal. After assuming responsibility for the city of Lhasa and its pilgrims, the $12^{\text {th }}$ century figure Lama Zhang goes about the process of sealing the 
city and its environs against both brigands and hunters. As a result, "In that place, laypeople, innumerable merchants, fish, wild animals, birds, and so on, horses, and cows all had peace and were cared for" (Lama Zhang 2004, pp. 542-543 ${ }^{17}$ ). By seamlessly including both humans and animals as the beneficiaries of his sealing practices, Lama Zhang suggests that the fearlessness this practice provided worked the same way for both humans and animals. I do not want to lay too much emphasis on this singular and early - account, and it is entirely possible that later authors understood the gift of fearlessness differently. But this vision of animal sentience - as able to respond to their environment with some degree of rationality-accords with the patterns I have observed throughout Tibetan texts, so it does not seem too far-fetched to imagine that many Tibetans assumed that animals were able to recognize the absence of hunters and respond by abandoning their fear of humans ${ }^{18}$.

Not only do these passages reflect an assumption that animals are intelligent and selfaware, their mental state is also strikingly similar to what we might expect a human to experience in similar circumstances. In particular, the types of suffering that they are said to experience are types of suffering that would be familiar to any human. Animals suffer from physical pain, as when they are beaten or forced to carry heavy loads. But they also suffer mentally, as when they fear for their lives. This type of suffering - both physical and mental - is similar to the suffering that human beings experience. This point is brought home by another passage from Patrül's Words of My Perfect Teacher, in which he discusses the suffering experienced by a prisoner awaiting punishment. As with animals awaiting slaughter, Patrül asks his readers to place themselves in the prisoner's position: "What to do? There is nowhere to run or hide, no refuge or protector. You cannot run away and do not know how to fly. [...] Now you must set out on the great path to the next life. How terrifying!" (Patrül Rimpoché 2009, p. $311^{19}$ ). In Patrül's presentation, the suffering experienced by a prisoner awaiting execution closely parallels the suffering experienced by animals awaiting slaughter. Both panic and look for an escape, a refuge. When none is found, both the prisoner and the animal experience deep fear at the realization that they will soon die. Rather than claiming that animals experience life in ways that humans cannot relate to, these depictions suggest that the division between human and animal experience is not so great.

The division between human and animal becomes even more blurred when we consider the common practice of intentionally viewing an animal as no different from one's own mother. This contemplative practice draws on the belief that all beings have lived an infinite number of lives: at some point in the past, simple maths suggests that any two beings have, in fact, been related as mother and child. In order to develop compassion towards animals, practitioners are sometimes asked to reflect on this and to see the animal in front of them as no different from their mother in this life, worthy of gratitude and love. Gampopa gives a concise presentation of this practice:

Again, imagine if you own mother was before you, old and frail. Yet others enslaved her, beat her, cut her, killed her, and cooked her. If this happened, would you not feel compassion? It is certain that all beings now born as animals were once your own mother, and that they suffer in just this way. How can you not feel compassion? Contemplate this and aspire for them to be free from suffering. (Gampopa 1989, p. $121^{20}$ )

21 By asking practitioners to explicitly identify the animal in front of them with their present mother, Gampopa emphasizes the similarity of human and animal experience. Animal suffering, in this view, is fundamentally similar to human suffering, to the 
degree that it can be understood by imagining a human in the animal's position. Animal and human suffering, it would seem, are not so different. Further, it is worth noting that the practice Gampopa suggests is not at all unusual in Tibetan Buddhism. It is so widespread, in fact, that it is often invoked without explanation, in the assumption that the audience will understand what is being referred to. For instance, the eighth Karmapa, Mikyö Dorjé, invokes this idea in the title of his anti-meat polemic, Letter on the Unsuitability of Eating the Meat of Our Past Mothers, apparently with the assumption that his readers would immediately understand the idea that the animal they are eating was once their mother. The ubiquity of this notion suggests that most, if not necessarily all, Tibetan Buddhist thinkers were comfortable intentionally thinking of animals as their mothers, blurring the lines that separate human from animal.

But these authors are not content to simply note the existence of animal suffering, they also ask their followers to actively address it. Tibetan Buddhism self-consciously adheres to Mahāyāna ethical norms, and in many Tibetan presentations the central aim of Buddhist practice is to alleviating the suffering of all beings - human, animal, and other. Jamgön Kongtrül explains this compassionate orientation, stating that one should "have the superior intention, the fortitude to shoulder the great responsibility of the welfare of all sentient beings solely by oneself" (Jamgön Kongtrül 2009, p. 108 ${ }^{21}$ ). One should, in other words, take on the responsibility of relieving the suffering of all others beings. Attempting to do so, for many Tibetans, is foundational to the Buddhist path. In the words of the Bön teacher Shardza Tashi Gyeltsen, "Compassion is the essence of all the Buddha's teachings" (Shardza Tashi Gyeltsen 2011, p. 14822).

When combined with the recognition that animals suffer, this call to compassion means that for most Tibetan Buddhist thinkers, humans must consider the impact of their actions on animals. Patrül Rinpoché summarizes this position well:

Animals experience unimaginable suffering. Therefore, whenever you see animal suffering, imagine that you are the animal and contemplate the suffering they are experiencing. Meditate with fierce compassion for all those born as animals. More specifically, if you have animals of your own, care for them with kindness and compassion. There is not a single animal - not even the smallest insect - that does not experience pleasure and pain. Further, there is not one that has not been our mother or father. For these reasons, think of them all with love and compassion. (Patrül Rinpoché 2009, pp. 116-11723)

For Patrül and many others, it is clear that animals have moral standing. When combined with these same authors' reflections on animals' mental abilities, it becomes clear that this moral standing is based on the animals' sentience. Animals, as we have seen, have rich emotional and mental lives, much like our own. In particular, animals like humans - have the ability to suffer. It is this sentience and ability to suffer that serves as the basis for their moral standing. Importantly, this means that animals have direct moral standing, rather than prudential moral standing. Humans need to take animal needs into consideration, in other words, because of the animals themselves, not simply because it is good for humans to do so. Animals have moral standing from their own side, not from ours.

Further, this moral standing is not simply theoretical: it is sufficient to justify concrete action in the world. Tibetan biographical and narrative literature is replete with stories of devout Buddhists practising compassion for animals by reducing their suffering. As discussed previously, wealthy individuals sometimes sought to alleviate animal suffering by purchasing land and banning hunting, giving animals the gift of 
fearlessness ${ }^{24}$. Jigmé Lingpa, for instance, once bought an entire mountain in order to curtail the collection of honey and the attendant harm this inflicted on bees (Jigmé Lingpa 1985b, pp. 208, 281, 393-395). Individuals also sometimes purchased animals destined for slaughter so that they could be ransomed (tshe thar ${ }^{25}$ ). Sometimes this was done in huge numbers, as when Khenpo Ngakchung's disciples are said to have ransomed thirty-one thousand animals (Khenpo Ngakchung 2000, p. 164 ${ }^{26}$ ). In other cases, individuals simply responded to observed animal suffering by trying to alleviate it, as when Shabkar Tsokdrük Rangdröl spent the better part of a day rescuing insects from a grassfire (Shabkar Tsokdrük Rangdröl 2003b, pp. 84b-85a ${ }^{27}$ ). These are not isolated or unusual actions, but rather common practices attested in the literature of virtually all Buddhist lineages in Tibet. Animals, it seems, carry enough moral standing to require humans to actually change their behaviour, actively addressing animal suffering.

\section{Yet not alike}

The fact that animals enjoy this level of moral standing, however, does not mean that the Buddhist intellectual tradition in Tibet sees humans and animals as morally equivalent. Animals and humans are both sentient beings and both carry moral standing, but their karma has driven them to be born in different situations, and these differences are important. In particular, Tibetans (like other Buddhists) have long assumed that animals are less intelligent than humans. Among other consequences, animals' lack of intelligence means that they are unable to practise religion ${ }^{28}$. "Animals are stupid", the $20^{\text {th }}$ century lama Longchen Yeshé Dorjé explains, "so they do not know how to recite even a single mani [mantra]" (Longchen Yeshe Dorjé 1991, p. $15^{29}$ ) Animals' assumed inability to practise religion can also be seen in a striking passage from Ra Yeshé Sengé's Biography of Ra Lotsawa, an eccentric $11^{\text {th }}$ century teacher. This text describes numerous miracles Ra Lotsawa performed, including one in which he does teach animals to practise religion:

Ra Lotsawa taught many dogs and mice to meditate, and did the same for those sheep that belonged to local landowners. He taught about six hundred young male and female sheep to meditate. [....] Then a scholar named Geshé Yönten Drakpa came forth to debate this point with him. The scholar said, "Meditation requires a body with the freedoms and riches [i.e.: a human body]. Animals lack this freedom; therefore it is impossible to teach them to meditate! Your claims are false!" The great teacher Ra Lotsawa replied, "Generally, you are correct. Nevertheless, in some particular cases it is not certain". (Ra Yeshé Sengé 1989, pp. 117-118 ${ }^{30}$ )

We will return to this passage later, but for now it is sufficient to note that it is the extraordinary nature of Ra Lotsawa's claim that attracts the scholar's scepticism. Echoing normative Buddhist sentiment, Geshé Yönten Drakpa argues that animals are flatly incapable of practising religion, so suggesting you have taught them to do so is nothing short of a lie. Ra Lotsawa largely concurs, agreeing that under normal circumstances it is impossible for animals to learn to meditate. His own miraculous ability to teach them merely proves the general rule that animals are too stupid to practise religion.

Because animals cannot practise Buddhism, humans' ability to alleviate their suffering is limited. In Tibetan Buddhist perspectives, suffering comes in many forms. It includes immediate physical and mental suffering, but also includes more existential forms of 
suffering experienced by all sentient beings. This latter form of suffering can only be alleviated through religious practice (particularly Buddhist practice). Since animals are incapable of doing so, they are unable to make progress towards resolving such existential suffering. Unless one has Ra Lotsawa's miraculous skill, therefore, a human's ability to alleviate animal suffering is limited. One can relieve the temporary physical pain an animal experiences, or even mental sufferings such as fear. But without the ability to teach an animal Buddhist practices, one cannot bring about the permanent end to suffering that characterizes enlightenment.

Further, Tibetan texts almost always claim that the types of suffering described above are inherent when a being is born as an animal. Being born as an animal is seen as an "unfortunate birth" (ngan 'gro), the result of previous negative karma. And once that karma results in taking birth as an animal, the attendant forms of suffering (stupidity, fear, and so on) are inescapable. In this regard, it is worth emphasizing the matter-offact tone employed when describing animal suffering. Neither Dungkar Losang Trinlé or Patrül Rinpoché gives any suggestion that their depiction of animal suffering is conditional. Instead, they are simply presenting the facts of the case: life as an animal is, by definition, characterized by suffering in these particular ways. A similarly matterof-fact tone can be found in many other descriptions of animal suffering as well. For these Tibetans, such suffering was simply an unavoidable part of life as an animal.

This emphasis on animals' stupidity and the unavoidability of animal suffering means that, generally speaking, animals' moral standing is lower than that of humans. Humans have the ability to make progress towards the permanent elimination of suffering. Further, they have the ability to use religious practice to increase their ability to help alleviate the suffering of others. These factors make a human life particularly valuable. More valuable, in fact, than an animal's. Shabkar Tsokdrük Rangdröl makes this clear in his Nectar of Immortality. In this text, Shabkar is a strong advocate for vegetarianism, pointing out repeatedly and insistently that eating meat causes animals to be killed. Meat eating, he makes clear, is the immediate cause of significant animal suffering. And yet there are circumstances when eating meat is allowed:

When is meat permitted? ... [It is allowed] if one is going on a long journey, such as from [the northeastern region of] Amdo to Central Tibet, and can find no other food. If you do not eat meat, your life will be in danger. Similarly, if one is weakened by illness and on the verge of death, so that not eating meat would cause them to die. If a great Bodhisattva who dwells on the grounds of liberation were to die, the torch of the teachings would be extinguished, while if they lived a long time it would be very beneficial for the teachings and beings. Therefore, when some great teachers reach old age and need to support their body's wind humour, they are allowed to eat meat. (Shabkar Tsokdrük Rangdröl 2003, pp. 609-61031)

Even for Shabkar, among the most adamant vegetarians in Tibetan history, the need to preserve human life outweighs the harm that eating meat inflicts on animals. Further, as Shabkar's emphasis on preserving the lives of great masters suggests, human superiority is intimately related to the ability to practise religion. Humans in general may take the lives of animals in order to save their own. But this is especially true in the case of high lamas, whose ability to teach means that they can alleviate suffering on a real, long-term level. In this regard, Shabkar is typical of the Tibetan tradition more broadly. For all Tibetans that I am aware of, human life clearly outweighs animal life. Humans can practise Buddhism, and thereby bring a lasting end to their own and others' suffering. Animals are unable to do so, and so will remain trapped in the 
ongoing cycle of birth and death. Given the choice between saving a human life and an animal's, therefore, Tibetan thinkers consistently side with the human. This is true not only of mainstream intellectuals, but even those such as Shabkar who are otherwise exceptionally strong advocates of practising compassion towards animals.

\section{Blurred lines}

While the Tibetan tradition as a whole insists that human moral standing is superior to animals', some authors suggest that their superiority may be minimal. We have already seen some examples suggestive of this, but the slippery nature of the human/animal distinction is brought home more fully in those few passages that suggest that animals are capable of thinking and acting with some level of ethical thought, and perhaps even capable of practising religion. As just discussed, most Buddhist thinkers - both in Tibet and elsewhere - have argued that animals are too stupid for ethical or religious conduct. But in at least a few places, Tibetan narrative literature suggests that there is some flexibility here, and that animals might be able to appreciate the dharma.

It is fairly common, for instance, for Tibetan autobiographies to claim that a particular teacher was able to pacify wild animals by teaching the dharma. Perhaps the most famous example of this can be found in Tsangnyon Heruka's Collected Songs of Milarepa, a $12^{\text {th }}$ century hermit who is among the most famous religious figures in Tibetan history. In one well-known episode, Milarepa is meditating in a forest when a frightened deer runs in front of him. Milarepa sings a dharma song, calming the deer down. Moments later, a large, angry hunting dog appears. Again, Milarepa calms it with the dharma. Finally, a hunter - the dog's owner - appears. He is livid that his dog and his quarry are both sitting calmly in front of Milarepa. Once again, Milarepa calms the hunter with a dharma song. This song is so effective, in fact, that the hunter renounces hunting and becomes a dedicated disciple (Tsangnyon Heruka 1999, pp. 430-44132). This passage makes clear that animals are able to respond positively when they are presented with the dharma, at least in Tsangnyon Heruka's estimation. Further, the story's parallel structure highlights the similarities between the way the dog, deer, and human responded to Milarepa's songs. Either the animals in this story are almost human, or the human is almost animal.

That the latter is even a possibility is brought home by a short passage in the late $19^{\text {th }}$ century teacher Jamgön Mipham's treatise on good governance, Guidance for Kings. In the verse opening of this work, Mipham praises the value of scriptural learning, concluding that, "those who are given scriptures that increase wisdom, but do not make use of them really are animals, aren't they?" (Jamgön Mipham 1984, p. $7^{33}$ ) Mipham's intention here is to praise scriptural study, not to discuss the relative intelligence of animals. At the same time, however, this line can be read to suggest that there can be some slippage between human and animal identity. Pointedly, Mipham claims that a human who fails to make use of religious resources is an animal (phyugs min nam), rather than is like an animal. By doing so he raises the possibility that the true difference between humans and animals is not a particular type of body, but rather a question of intelligence. Humans, on this reading, are only human if they actually make use of their intelligence. Again, the line between human and animal becomes obscured. While the animals in the Milarepa story clearly respond to and appreciate the dharma, however, there is no suggestion that they become disciples or actively practise religion 
in the way that the hunter does. This story and the many others like it can be read as simply suggesting that animals can be calmed or pacified by the dharma, rather than asserting that they are capable of actual religious practice. A few stories, however, question even this seemingly firm boundary between human and animal. To illustrate this, we can return to the passage from Ra Yeshé Sengé's Biography of Ra Lotsawa quoted previously. In this passage, we may recall that Ra Lotsawa claims to have taught numerous dogs, mice, and sheep to meditate. His claim is met by scepticism on the part of a scholar, who points out that animals are incapable of religious practice. Ra Lotsawa admits the Geshé is right, but only up to a point: "Generally, you are correct. Nevertheless, in some particular cases it is not certain" (Ra Yeshé Sengé 1989, pp. 117-118 $8^{34}$ ). This passage confirms that animals are generally incapable of meditating or otherwise practising religion. At the same time, however, it also suggests that this might not be the animals' fault. The animals in question were presumably normal animals, and yet Ra Lotsawa was able to teach them. The key factor, in this particular story, is not the animals' own capacity, but the presence or absence of a sufficiently skilled teacher. This is just a short passage, one miracle among many in the biography of Ra Lotsawa. It should not, therefore, be understood to represent the Tibetan Buddhist tradition as a whole, or even a clear statement of this author's own understanding. It does, however, hold out the possibility that some Tibetans were comfortable with the idea that, given the right conditions, animals might be able to practise religion after all.

It is worth emphasizing that the animals discussed in this and similar passages are not metaphorical, such as those found in Aesop's Fables, or in some Buddhist Jataka literature ${ }^{35}$. Such literary representations of animals are common in Tibetan literature. But in the passages cited here, the authors are seeking to give naturalistic descriptions of actual animals. As such, these passages represent their author's understanding of how animal minds work, and in almost all cases those animal minds are understood to be rich in both thought and emotion. Further, these animal minds are presented in ways strikingly similar to human minds. This does not mean that they are fully equivalent, of course. We may recall that Patrül describes lambs as "only stupid animals" (Patrül Rimpoché 2009, p. 12136), and Ra Yeshé Sengé never disputes that under most circumstances, animals are incapable of practising Buddhism. Nevertheless, the overall tenor of these passages suggests that animals experience and process their world in ways that would be familiar to a human.

Overall, it is clear that in the view of most Tibetan intellectuals, animals carried significant moral standing. This moral standing does not rise to the level enjoyed by humans, largely because only humans are able to practise religion, and so only humans are able to address the root causes of suffering. Nevertheless, despite this insistence that animals are below humans, these authors also suggest that the gap between these categories is minimal. Animals experience the world, we are told, in ways that are fundamentally similar to human experience. Further, these authors repeatedly encourage their readers to self-consciously view animals as similar to their mothers, and to act accordingly. Even though this may not mean that animals are truly morally equivalent to humans, it suggests that humans should act as if they are. Even though animals are lower than humans, therefore, they nevertheless retain a high level of moral standing, and it is incumbent upon humans to consider the impact of their actions on animal experience. The contemporary Central Tibetan teacher Rasé Könchok Gyatso summarizes this attitude well: "Among the beings in this world, it is very hard 
to find one that does not cherish life, that does not avoid hurting itself, or that is not afraid. All beings are the same in cherishing life and being aware of happiness and suffering. [...] So do not separate animals as 'other,' but always treat them with equality. This is why [the Buddha] teaches that it is inappropriate to harm any being that experiences itself as alive and embodied, even an insect" (Rasé Könchok Gyatso 2004, p. $\left.10^{37}\right)$.

\section{Some contrasts}

Across the board, then, Tibetan Buddhist literature consistently presents a vision in which animals enjoy significant moral standing. This conclusion is interesting in its own right, but it is also striking because it differs dramatically from the perspective taken in some of the most influential studies of Buddhism and animals to date. In their analysis of Buddhist animal ethics, some scholars have concluded that while Buddhism does grant animals some degree of moral standing, it is minimal when compared with humans. Humans, in this vision, should not actively persecute animals, but also do not need to actively seek to alleviate their suffering. In the most influential such assessment, Paul Waldau argues in The Specter of Speciesism. Buddhist and Christian Views of Animals that Buddhism's insistence that animals are inferior to humans outweighs any sense of kinship between animals and humans due to their shared status as sentient beings. This tendency is so strong, Waldau believes, that Buddhism is "speciesist", by which he means, "the inclusion of all human animals within, and the exclusion of all non-human animals from, the moral circle" (Waldau 2001, p. 38). Even when the textual tradition explicitly endorses an ideal of non-harm towards animals, Waldau asserts, this is only provisional: "some level of concern can be accorded to other animals when their interests are not in conflict with the interests of humans" (ibid., p. 152). Even when animals seem to have moral standing, in other words, this applies only when it is convenient. In Waldau's interpretation, Buddhism's dim view of animal sentience means that they are entirely, or almost entirely, beyond the moral sphere, and humans have few ethical responsibilities towards them. Buddhism grants animals little, if any, moral standing.

Not all scholars share such a negative interpretation of Buddhism's attitude towards animals. There is not space here for a full summary of all points made in the rich literature on Buddhism and animal ethics, but it is worth mentioning several recent works have explicitly pushed back against Waldau. Drawing on the idea that humans and animals share an essential status as sentient beings, for instance, Norm Phelps argues passionately that, "Buddhism recognizes no essential distinction between humans and animals. There is no line that can be drawn between us, no Great Divide" (Phelps 2004, p. 33). Phelps's arguments here have been picked up by other scholars sympathetic to the plight of animals, notably Lisa Kemmerer, whose Animals and World Religions - one of very few textbooks on the topic of religion and animals - quotes Phelps extensively and approvingly (Kemmerer 2011, pp.91-126). For her part, Bronwyn Finnigan has argued specifically against Waldau's claims that Buddhism is speciesist, "If speciesism is the view that only members of the human species have moral significance, however, then it does not follow from the above considerations. Animals are included within the scope of the first precept and so have moral significance in Buddhism" (Finnigan 2017, p. 3). James Stewart also argues specifically 
against Waldau's speciesism claim, suggesting that while some of Waldau's points are well made, they do not amount to a claim of speciesism, unless that term is re-defined to mean anything less than a strict moral equivalence between humans and animals (Stewart 2014, pp. 644-645).

Despite these critical voices, however, Waldau's position remains broadly influential ${ }^{38}$. His emphasis on placing animals' moral standing far below humans', however, diverges strongly from what I see in the Tibetan tradition. As in Waldau's analysis of South Asia texts, the Tibetan works I examine display a tension between a vision of animals as cosentient beings and one that portrays them as stupid and incapable of religious practice. While Waldau suggests that Buddhism tends to reify the difference between humans and animals, however, I see an emphasis on blurring that distinction. It is beyond the scope of this paper to engage in a full critical analysis of Waldau's position $^{39}$. It is my hope, however, that this paper will serve - alongside the work of Phelps, Stewart, Finnigan and others - to demonstrate that not all Buddhist thinkers in all cultural contexts held such a dim view of the moral standing of animals ${ }^{40}$.

\section{Conclusion}

41 Over the course of this article, I have discussed Tibetan Buddhist perspectives on the moral standing of animals. The Tibetan authors I have cited and discussed are invariably elite religious scholars. They were well versed in religious literature, and their opinions draw on normative Buddhist concepts. It is worth noting, therefore, that the general picture of animal moral standing that I have outlined in this article accords well with the way that non-elite Tibetans interacted with their animals. As Nancy Levine's article in this present volume illustrates well, many Tibetan nomads have a complex, multifaceted relationship with their animals (Levine, this volume). They depended on the products of their yaks and sheep for survival, but also saw their animals as individuals with personalities and rich emotional lives. My own, admittedly limited, experience with Tibetan nomads suggests that they very much see their animals as sentient creatures with significant moral standing, to the extent that harming them should only be undertaken when necessary. This impression aligns well with Gillian Tan's recent analysis, wherein she suggests that the nomads she worked with saw a kinship between humans and animals that did not exist between humans and trees, rocks, or other aspects of the natural world (Tan 2016, p. $9^{41}$ ). A full analysis of nomadic attitudes towards the moral standing of animals is beyond the scope of this article, but an initial look suggests that it may not differ dramatically from the elite, religious perspective discussed here.

Like other forms of Buddhism, the Tibetan tradition is diverse, with a variety of distinct practices and points of view. Among other things, this means that some individuals and lineages have a more expansive view of animal ethics than others. Some bring up the plight of animals consistently, repeatedly asking their audience to respect and be kind to them. For others, animals are mentioned only as an afterthought, if at all. Nevertheless, despite these differences, most Tibetan thinkers agree on the basic point that animal suffering matters, and that humans should take that suffering into account when acting in the world. They agree, in other words, that animals have moral standing. Further, there is broad agreement within the tradition on the basis for that moral standing. Animals are sentient beings, just as humans are. As such, they have 
rich mental lives, thinking, feeling, and suffering in ways that would be familiar to any human. Animals were assumed to be less intelligent than humans, and incapable of religious practice. Human needs, therefore, did outweigh animal needs. While the moral standing of animals did not rise to the level of humans', however, this does not mean it was inconsequential. A variety of common practices reinforced the idea that while animals were below humans, they nevertheless mattered a great deal. Despite their limited intelligence, therefore, it is clear that in the Tibetan tradition animals enjoyed significant moral standing.

\section{BIBLIOGRAPHY}

\section{Tibetan Language Bibliography}

Dunkar Lozang Trinlé (dung dkar blo bzang 'phrin las) 2004 Chos lugs grub mtha' khag gi gzhi rtsa'i shes yon mdzub mo ri ston [Doxography of Buddhist systems], mKhas dbang Dung dkar Blo bzang 'phrin las kyi gsung 'bum, vol. 3 (pe cin, Mi rigs dpe skrun khang).

Gampopa (sgam po pa bsod nams rin chen) 1989 Dam chos yid bzhin nor bu thar pa rin po che'i rgyan [Jewel ornament of liberation] (Khreng tu'u, Si khron mi rigs dpe skrun khang).

Jamgön Kongtrül (blo gros mtha' yas) 2009 Lam rim ye shes snying po'i 'grel pa [Commentary on the gradual path of luminous wisdom], vol. 10, Blo gros mtha' yas pa'i mdzod (Kathmandu, Rigpe Dorje Publications).

Jamgön Mipham (Mi pham rgya mtsho) 1984 rGyal po lugs kyi bstan bcos gzhi skyong ba'i rgyan [Guidance for kings], gGung 'bum / Mi pham rgya mtsho, vol. 1 (Paro, Lama Ngodrup and Sherab Drimey).

Jigmé Lingpa ('Jigs med gling pa) 1985a Yon tan rin po che'i mdzod dga' ba'i char [Treasury of precious qualities], 'Jigs med gling pa gsung 'bum, vol. 1 (Gangtok, Pema Thinley for Dodrupchen Rinpoche).

1985b Yul lho rgyud du byung ba'i rdzogs chen pa rang byung rdo rje mkhyen brtse'i 'od zer gyi rnam thar pa legs byas yongs 'du'i snye ma [The autobiography of Jigmé Lingpa], 'Jigs med gling pa gsung 'bum, vol. 9 (Gangtok, Pema Thinley for Dodrupchen Rinpoche).

Khenpo Ngakchung (Ngag dbang dpal bzang) 2000 mKhan po Ngag chung gi rang rnam [The autobiography of Khenpo Ngakchung] (Khreng tu'u, Si khron mi rigs dpe skrun khang).

Lama Zhang (Bla ma Zhang) 2004 Dus gsum kyi sangs rgyas kyi dgongs pa'i nying phugs zab rgya'i don gtan la 'bebs byed phan byed nyi ma'i snying po [Beneficial essence of the sun], dPal ldan tshal pa bka' brgyud kyi bstan pa'i mnga' bdag zhang g.yu brag pa brtson 'grus grags pa'i gsung 'bum rin po che, vol. 2 (Kathmandu, Gam po pa Library).

Longchen Yeshé Dorjé (Klong chen ye shes rdo rje) 1991 Yon tan rin po che'i mdzod kyi mchan 'grel theg gsum bdud rtsi'i nying khu [Quintessence of the three paths] (Delhi, Shechen Publications). 
Mikyo Dorjé (Mi bskyod rdo rje) n.d. Gangs ri'i khrod na gnas pa gtso bor gyur pa skyabs med ma rgan tshogs la sha zar mi rung ba'i springs yig sogs [Letter on the unsuitability of eating the meat of our past mothers], NGMPP Reel no. E 2943/4.

Patrül Rinpoché (dPal sprul o rgyan 'jigs med chos kyi dbang po) 2009 sNying tig sngon 'gro'i khrid yig kun bzang bla ma'i zhal lung [The words of my perfect teacher], dPal sprul o rgyan 'jigs med chos kyi dbang po'i gsung 'bum 7 (Chengdu, Si khron dpe skrun tshogs pa \& Si khron mi rigs dpe skrun khang).

Ra Yeshé Sengé (Ye shes seng ge) 1989 mThu stobs dbang phyug rje btsun rwa lo tsā ba'i rnam par thar pa kun khyab snyan pa'i rnga sgra [Biography of Ra Lotsawa] (Zi ling, mTsho sngon mi rigs dpe skrun khang).

Rasé Könchok Gyatso (Ra sed dKon mchog rgya mtsho) 2004 Mi 'jigs skyabs kyi sbyin pa dkar zas ring lugs kyi phan yon bstan pa zhi bde'i lam bzang [Benefits of being vegetarian] (Lha sa, Bod ljongs mi dmangs dpe skrun khang).

Shabkar Tsokdrük Rangdröl (Zhabs dkar Tshogs drug rang grol) 2003a Legs bshad bdud rtsi’i chu rgyun [The nectar of immortality] Zhabs dkar tshogs drug rang grol gyi bka' 'bum, vol. 12 (New Delhi, Shechen Publications).

2003b Zhabs dkar tshogs drug rang grol gyi rnam thar rgyas pa yid bzhin gyi nor bu bsam 'phel dbang gi rgyal po [The autobiography of Shabkar] Zhabs dkar tshogs drug rang grol gyi bka' 'bum, vol. 1 (Delhi, Shechen Publications).

Shardza Tashi Gyeltsen (Shar rdza bKra shis rgyal mtshan) 2011 Sha'i nyes dmigs mdor bsdus [The faults of meat], Kun mkhyen shar rdza pa bskra shis rgyal mtshan gyi gsung 'bum, vol. 15 (Khreng tu'u, Si khron dpe skrun tshogs pa \& Si khron mi rigs dpe skrun khang).

Tsangnyon Heruka (gTsang smyon He ru ka) 1999 rNal 'byor gyi dbang phyug chen po mi la ras pa'i rnam mgur [Collected songs of Milarepa] (Zi ling, mTsho sngon mi rigs dpe skrun khang).

\section{English Language Bibliography}

Barstow, G. 2013 Buddhism between abstinence and indulgence. Vegetarianism in the life and works of Jigmé Lingpa, Journal of Buddhist Ethics 20, pp. 73-104.

2017 Bold judgements on eating meat, in H. Gayley \& J. Shapiro (eds), A Gathering of Brilliant Moons. Practice Advice from the Rime Masters of Tibet (Boston, Wisdom Publications), pp. 97-108.

2018 Food of Sinful Demon. Meat, Vegetarianism, and the Limits of Buddhism in Tibet (New York, Columbia).

Bryant, E. 2006 Strategies of vedic subversion. The emergence of vegetarianism in post-vedic India, in P. Waldau \& K. C. Patton (eds), A Communion of Subjects. Animals in Religion, Science, and Ethics (New York, Columbia), pp. 194-203.

Chapple, C. 2006 Inherent value without nostalgia. Animals and the Jaina tradition, in

P. Waldau \& K. C. Patton (eds), A Communion of Subjects. Animals in Religion, Science, and Ethics (New York, Columbia), pp. 241-249.

1993 Nonviolence to Animals, Earth, and Self in Asian Traditions (New York, SUNY).

Cottington, J. 1978 “A brute to the brutes?”. Descartes' treatment of animals, Philosophy 53(206), pp. 551-559.

Finnigan, B. 2017 Buddhism and animal ethics, Philosophy Compass 12(7) [online, URL: https:// doi.org/10.1111/phc3.12424]. 
Framarin, C. 2014 The argument for Ahimsa in the Anuśāsanaparvan of the Mahābhārata, in N. Dalal \& C. Taylor (eds), Asian Perspectives on Animal Ethics. Rethinking the Nonhuman (London, Routledge), pp. 112-128.

Ga Errang 2016 Tibetan identity and Tibetan Buddhism in trans-regional connection. The contemporary vegetarian movement in pastoral areas of Tibet (China), Études mongoles \& sibériennes, centrasiatiques \& tibétaines 47.

Gampopa 2017 Ornament of Precious Liberation, transl. by K. Holmes (Somerville, Wisdom).

Gayley, H. 2017 The compassionate treatment of animals, Journal of Religious Ethics 45(1), pp. 29-57. Gruen, L. 2014 The moral status of animals, in E. N. Zalta (ed.), The Stanford Encyclopedia of Philosophy (Metaphysics Research Lab, Stanford University) [online, URL: https:// plato.stanford.edu/archives/fall2014/entries/moral-animal/, accessed 12 April 2018].

Harris, I. 2006 A vast unsupervised recycling plant. Animals and the Buddhist cosmos, in P. Waldau \& K. C. Patton (eds), A Communion of Subjects. Animals in Religion, Science, and Ethics (New York, Columbia), pp. 207-217.

Harvey, P. 2000 An Introduction to Buddhist Ethics. Foundations, Values and Issues (Cambridge, Cambridge).

1989 Buddhist attitudes to and treatment of non-human nature, Ecotheology: Journal of Religion, Nature \& the Environment 5(4), pp. 35-50.

Holler, D. 2002 The ritual of freeing lives, in J. Ardussi (ed.), Tibet, Past and Present. Religion and Secular Culture in Tibet (Leiden, Brill).

Horner, I. B. 1967 Early Buddhism and the Taking of Life, Kandy, Buddhist Publication Society, The Wheel Publication 104).

Huber, T. 2003 The chase and the dharma. The legal protection of wild animals in pre-modern Tibet, in J. Knight (ed.), Wildlife in Asia. Cultural Perspectives (London, Routledge).

Jamgön Mipham, J. 2017 The Just King. The Tibetan Buddhist Classic on Leading an Ethical Life (Boulder, Snow Lion).

Jigme Lingpa \& Longchen Yeshe Dorje, Kangyur Rinpoche 2010 Treasury of Precious Qualities (Boston, Shambhala).

Karmapa, O. T. D. 2017 Interconnected. Embracing Life in Our Global Society (New York, Simon and Schuster).

Kemmerer, L. 2011 Animals and World Religions (New York, Oxford).

Keown, D. 2000 Contemporary Buddhist Ethics (London, Routledge).

Khenpo Ngawang Palzang 2014 Wondrous Dance of Illusion. The Autobiography of Khenpo Ngawang Palzang (Boston, Shambala).

Lecso, P. A. 1988 To do no harm. A Buddhist view on animal use in research, Journal of Religion and Health 27(4), pp. 307-312.

Levine, N. E. (this volume) A multifaceted interdependency. Tibetan pastoralists and their animals, Études mongoles \& sibériennes, centrasiatiques \& tibétaines 50 [online, URL: http:// journals.openedition.org/emscat/3822, accessed 4 March 2019].

Macdonald, A. W. 1973 The lama and the general, Kailash 1(3), pp. 225-234. 
Mcdermott, J. P. 1989 Animals and humans in early Buddhism, Indo-Iranian Journal 32(4), pp. 269-280.

Nelson, L. 2006 Cows, elephants, dogs and other lesser embodiments of Atman. Reflections on Hindu attitudes towards non-human animals, in P. Waldau \& K. C. Patton (eds), A Communion of Subjects. Animals in Religion, Science, and Ethics (New York, Columbia), pp. 179-193.

Ohnuma, R. 2017 Unfortunate Destiny. Animals in the Indian Buddhist Imagination (New York, Oxford).

Padmasambhava \& Jamgön Kongtrül 1999 The Light of Wisdom, vol. 1 (Boudhanath, Rangjung Yeshe).

Patrul Rinpoche 1998 The Words of My Perfect Teacher (Boston, Shambhala).

Phelps, N. 2004 The Great Compassion. Buddhism and Animal Rights (New York, Lantern Books).

Pu Chengzhong 2014 Ethical Treatment of Animals in Early Chinese Buddhism. Beliefs and Practices (Newcastle, Cambridge Scholars).

Ra Yeshé Sengé 2015 The All-Pervading Melodious Drumbeat. The Life of Ra Lotsawa (New York, Penguin Classics).

Ricard, M. 2016 A Plea for the Animals. The Moral, Philosophical, and Evolutionary Imperative to Treat All Beings with Compassion (Boston, Shambhala).

Shabkar Tsokdruk Rangdrol 2001 The Life of Shabkar. The Autobiography of a Tibetan Yogin (Ithaca, Snow Lion).

2004 Food of Bodhisattvas. Buddhist Teachings on Abstaining from Meat (Boston, Shambhala).

Singer, P. [1975] 1990 Animal Liberation (New York, New York Review Books).

Steiner, G. 2006 Descartes, christianity, and contemporary speciesism, in P. Waldau \& K. C. Patton (eds), A Communion of Subjects. Animals in Religion, Science, and Ethics (New York, Columbia), pp. 117-131.

Stewart, J. 2014 Violence and nonviolence in Buddhist animal ethics, Journal of Buddhist Ethics 21, pp. 623-656.

2015 Vegetarianism and Animal Ethics in Contemporary Buddhism (London, Routledge). 2017 Dharma dogs. Can animals understand the dharma? Textual and ethnographic considerations, Journal of Buddhist Ethics 24, pp. 39-62.

Sulek, E. R. 2011 Disappearing sheep. The unexpected consequences of the emergence of the caterpillar fungus economy in Golok, Qinghai, China, Himalaya, the Journal of the Association for Nepal and Himalayan Studies 30(1), pp. 9-22.

2016 Caterpillar fungus and the economy of sinning. On entangled relations between religious and economic in a Tibetan pastoral region of Golog, Qinghai, China, Études mongoles \& sibériennes, centrasiatiques \& tibétaines 47.

Tan, G. G. 2016 "Life" and "freeing life" (tshe thar) among pastoralists of Kham. Intersecting religion and environment, Études mongoles \& sibériennes, centrasiatiques \& tibétaines 47.

Tsangnyön Heruka 2017 The Hundred Thousand Songs of Milarepa, translated by C. Stagg (Boston, Shambhala).

Waldau, P. 2000 Buddhism and animal rights, in D. Keown (ed.), Contemporary Buddhist Ethics (London, Routledge).

2001 The Specter of Speciesism. Buddhist and Christian Views of Animals (New York, Oxford). 
Waldau, P. \& K. C. Patton (eds) 2006 A Communion of Subjects. Animals in Religion, Science, and Ethics (New York, Columbia).

Wiley, K. 2006 Five-sensed animals in Jainism, in P. Waldau \& K. C. Patton (eds), A Communion of Subjects. Animals in Religion, Science, and Ethics (New York, Columbia), pp. 250-255.

Yamamoto, C. 2014 Vision and Violence. Lama Zhang and the Politics of Charisma in Twelfth century Tibet (Leiden, Brill).

\section{NOTES}

1. This article has benefitted from the support of numerous people and institutions. At the outset, I would like to thank the University of Virginia, the Fulbright US student program, Otterbein University, and Oregon State University for the financial support necessary to undertake the research behind this paper. I am also indebted to the two reviewers whose comments have greatly improved this paper, as well as the many colleagues who have suffered through my presentations on this topic with enough patience and kindness to offer feedback.

2. There have been far too many studies of Buddhist approaches to animal ethics to list here, but some important recent contributions include: Finnigan 2017, Harvey 1989, Ohnuma 2017, Stewart 2017, Waldau 2001.

3. For a concise discussion of the latter, see Steiner 2006.

4. On Tibetan animal ethics in general, see Ga Errang 2016, Gayley 2017.

5. For a good introduction to this topic, see Gruen 2014.

6. For a good discussion of these different types of moral standing in the context of the Hindu epic Mahābahārata, see Framarin 2014, pp. 112-128.

7. Throughout this article, all English translations from Tibetan sources are my own, with the original Tibetan given in a footnote. When an alternate translation has been published (as with this source), I will note that fact in the footnote. Page numbers provided in parentheses always refer to the original Tibetan text.

de'i 'bras bu la yangs gsum las/ rnam par smin pa'i 'bras bu ni/ yi dwags su skye bar 'gyur ro/ rgyu mthun gyi 'bras by ni/gal te mir skyes na yang 'dod chags shas che bar 'gyur ro/ dbang gi 'bras by ni/ yul 'bru ngan pa'i sar skye bar'gyur ro/

For an alternative translation, see Gampopa 2017, p. 81.

8. The implications of the continuity between the human and animal realms has been widely discussed in the literature on Buddhism and animal ethics. For a critical discussion of this point, see Waldau 2001, pp. 137-141.

9. One interesting point of potential controversy involves the question of microscopic creatures such as bacteria. I have heard some contemporary Tibetans explain that bacteria are included within the semchen sphere, while others explain that they are better understood as plants. As interesting as it is, however, a detailed discussion of this distinction is beyond the scope of this paper.

10. de la sdug bsngal shes par bya ba ni//gnas rigs drug po dma' 'am mtho yang rung//sdug bsngal 'gyur dang khyab pa 'du byed kyis//dam la ma bzhang 'khor ba yod ma yin/ For an alternative translation, see Jigme Lingpa et al. 2010, p. 32.

11. bkol zhing spyod pa'i sdug bsngal/ mi dang lhan du gnas pa'i dud 'gro'i nang nas khag cig mis bran du bkol nas mi theg pa'i khal 'gel ba dang/rmon pa rgyag pa/ steng du bzhon pa sogs 
gang 'dod byed pa dang/ dud 'gro khag cig sha dang pags pa/ rwa co sogs kyi don du bsad de srog la rang dbang med $p a /$

12. mi yul gyi dud 'gro mis bdag tu ma bzung ba'i ri dwags la sogs pa rnams ni 'jigs skrag gi snang ba kho na la spyod/zas kham gang za yang bag mi pheb bzhin du za/gcig gis gcig la za zhing/rngon pa dang gcan gzan la sogs bsod pa po grangs mang/ khras bye'u dang bye'us 'bu gsod pas mtshon/gcig gis gcig gsod pa'i las ngan pa kho na rtag tu gsog/

For an alternative translation, see Patrul Rinpoche 1998, p. 76.

13. sdig can shan pa zer bde'i lag tu rang gi skye ba sngon ma'i pha dang/ma dang/spun zla gnyen bshes la sogs pa de dag mthar chags su rtsis sprod byas ba'i tshe/ ma rgan de dag lus 'dar phri li li/ mig mchi ma khram khram/dbugs spud pa lhed lhed pa'i ngang nas 'di snyam du/ da ci drag kyi hud/ 'bros sa ni med/ 'phur ni mi thug/da lta nyid du sa 'dir dim na dim na snyam pa'i sdug bsngal dos drag la lcid che/ 'jigs skrag gi snang ba dmyal me'i dong khar lhags pa lta bu'i ngang der/lus gnam sa bsgyur/ brang dred tsha lam lam byed cing mig spo hur hur/lta bzhin pa de'i lto ba gris kha phye/ lag pa shad de btang nas 'gul ba tsam yang med par 'jig rten phyi ma'i lam por btang ba yin 'dug pas/

14. skyes pa de dbang po thams cad rdzogs/ bde sdug gi tshor ba dang ldan/lus kyang nyams brtas/gson pa'i dang po skyid par yod pa'i dus su 'phral du bsad pa yin/ rmongs pa dud 'gro yin yang 'chi ba la ni 'tsher/gson pa la ni dga'/ gnad gcod kyi sdug bsngal ni myong/

For an alternative translation, see Patrul Rinpoche 1998, p. 80.

15. khyad par bsha' lug sogs gsod pa'i skabs/dang po mang po'i khyu nas bzung ba'i tshe/ de la 'jigs skrag gi snang ba bsam gyis mi khyab pa yod pas/[...] za phod pa 'di las kyi srin po dngos so 'dug/

For an alternative translation, see Patrul Rinpoche 1998, p. 203.

16. It is worth noting that in some early formulations, the gift of fearlessness meant protecting animals (and humans) from carnivorous animals. In later formulations, this became standardized so that this gift meant to protect all animals from human predation. For more on this practice, and the related practice of "sealing the hills", see Huber 2003, pp. 40-41.

17. de yi yul na ser chags dang/tshong pa dpag tu med pa dang/ nya dang ri dwags bya la sogs/ rta phyugs mang po bde zhing 'tsho/

For an alternative translation, see Yamamoto 2014, p. 198.

18. It may be worth noting that this practice was often effective in making wild animals behave without a fear of humans. For the account of one western explorer startled to find animals living without fear under the protection of a monastery, see Macdonald 1973, p. 226.

19. da ci byed bros sa dang gab sa/skyabs dang skyong pa ni med/'bros ni mi nus/'phur ni mi shes/... tshe phyi ma'i lam po cher 'gro dgos pa 'di ya re nga

For an alternative translation, see Patrul Rinpoche 1998, pp. 201-202.

20. yang bdag gi ma de sa phyogs 'di na rgas shing dman pa'am/gzhan dag gis dbang med par bkol zhing spyad pa'am/ brdeg cing 'tshog pa'am/ bsad cing bcad pa la sogs pa byed cing 'dug na snying rje'o/ /de bzhin du dud 'gror skyes pa'i sems can thams cad kyang bdag gi ma yin nges na/ sdug bsngal de lta bus ni nyams thag na/ ci ste snying mi rje ste/de rnams sdug bsngal dang bral bar 'dod pa'i snying rje bsgom mo/

For an alternate translation, see Gampopa 2017, p. 95.

21. sems can ma lus pa'i don gyi khur chen rang nyid kho nas khyer ba'i lhag bsam gyi snying stobs dang ldan $p a /$

For an alternative translation, see Padmasambhava \& Jamgön Kongtrül 1999, p. 117. 
22. sangs rgyas bstan pa'i nyams len thams cad mdor hril gyis dril na rtag tu tshad med snying rje chen po

For a complete translation of this text, see Barstow 2017.

23. de lta bu sdug bsngal bsam gyis mi khyab pa la spyod pa yin pas/de ltar sdug bsngal ba'i sems can mthong tsa na de rang nyid yin pa'i blo bzhag nas sdug bsngal ci tsam 'dug la sogs pa zhib tu bsam nas/dud 'gro'i gnas su skyes pa spyi la snying rje drag po bsgom zhing khyad par rang la bsten pa'i dud 'gro sogs yod na byams brtses skyong ba dang/tha na 'bus sbrang dang srog chags phra mo tshun chad la'ang bde sdug gi tshor ba med pa ni gcig kyang med la/ de thams cad kyang rang gi pha ma ma byas pa'ang med pas teams cad la beams pa dang saying roe bsgom pa

For an alternative translation, see Patrul Rinpoche 1998, p. 77.

24. For more on the practice of sealing hills against hunters, see Huber 2003.

25. For a fuller discussion of this practice, see Holler 2002, and Tan 2016.

26. For the same passage in English, see Khenpo Ngawang Palzang 2014, pp. 169-170.

27. For an alternative translation, see Shabkar Tsokdruk Rangdrol 2001, p. 103.

28. For a particularly nuanced discussion of animal's inability to practise religion because of their stupidity in the context of Sri Lankan Buddhism, see James Stewart's recent article "Dharma Dogs" (Stewart 2017). Stewart reports that, as in the Tibetan tradition, contemporary Sri Lankan Buddhists assume that while animals may acquire some measure of positive karma through association with Buddhist cites, personages and texts, their lack of intelligence means that they are incapable of focused Buddhist practice.

29. blun pas ma ni rdog cig 'don mi shes pa For an alternative translation, see Jigmé Lingpa \& Longchen Yeshe Dorje 2010, p. 118. 30. khyi dang byi la mang por yang sgom btab/gnas po tshang gi lug khyu la'ang de ltar mdzad pas/lug ma bu drug brgya tsam la sgom thebs pas [...] de'i tshe dge bshes yon tan grags pa bya ba gcig rtsod pa byed du byung ste/ bsgom btab pa la dal 'byor gyi lus rten thob pa dgos/dud 'gro mi khom pa'i gnas yin pas sgom thebs mi srid/ khyod kyi de rdzun yin zer ba la/bla ma rwa chen gyi zhal nas/spyir btang la de ltar yin kyang khyad par la nges pa med/

For an alternative translation, see Ra Yeshé Sengé 2015, p. 108.

31. de la gnang tshul ni/ so thar skabs su/ yul mdo smad nas dbus gtsang lta bu'i thag ring re phyin tshe lam nas za rgyu ma rnyed/ ma zos na srog gi bar chad du 'grol dus dang/ nad pa zungs zad 'chi la nye ba sha zhig ma zos na mi 'tsho bar thag chod pa'i dus dang/ byang sems skabs su sar gnas kyi byang chub sems dpa' chen po gshegs na bstan pa'i sgron me nub/sku tshe yun ring 'tsho na bstan 'gro'i don rlabs chen 'ong ba'i bla ma skyes chen 'ga' res skun bgres dus rlung bcos 'dra byed dgos pa'i dus dang/

For an alternative translation, see Shabkar 2004, p. 121.

32. For a complete translation of this story, see Tsangnyön Heruka 2017, pp. 285-298.

33. cho don 'dod dang thar pa yi//'byung gnas chen po rig pa yin//rig pa spel ba'i gzhung bzang po/ /byin kyang mi mkho phyugs min nam

For an alternative translation, see Jamgon Jamgön Mipham 2017, p. 12.

34. spyir btang la de ltar yin kyang khyad par la nges pa med/

For an alternative translation, see Ra Yeshé Sengé 2015, p. 108.

35. For an excellent analysis of the literary role of animals in the Jataka stories in their Indian Buddhist context, see Ohnuma 2017, pp. 41-94.

36. rmongs pa dud 'gro yin yang

For an alternative translation, see Patrul Rinpoche 1998, p. 80. 
37. 'jig rten thog sems can su 'dra zhig yin rung rang gi srog la ma gces pa dang 'chi ba la mi 'tsher zhing mi skrag pa ni shin tu dkon la/ 'gro ba thams cad srog dang bcas pa dang/ bde sdug gi tshor ba yod pa gcig mtshungs yin pa'i phyir/rang ci 'dra ba gzhan kun kyang de 'dra yin stabs/der brten sangs rgyas kyi thugs brtse ba chen pos ni nye ring med par kun la snyoms pas mi zhes tshur mi gcod/dud 'gro zhes phar mi gcod par rtag tu 'dra mnyam gnang zhing/srog chags phra mo tshun chad srog dang bcas pa'i lus can kun la rang gi nyams la gzhigs nas gnod pa byed mi rung bar gdams te/

38. Reiko Ohnuma's recent Unfortunate Destiny, for instance, draws heavily and largely positively on Waldau's analysis. While Ohnuma does state that "some aspects of Waldau's claim of Buddhist speciesism are perhaps overstated" (Ohnuma 2017, p. 16), she is also insistent that, "Despite the much-vaunted continuity and fluidity of the karmic hierarchy (such that human beings can be re-born as animals, and animals as human beings), there is nevertheless a strong concern with keeping the basic categories of rebirth - the five or six gatis [realms of re-birth] - distinct from each other and in proper hierarchical order" (ibid., pp. 16-17).

39. It is worth noting that while Waldau explicitly claims to speak for Buddhism in general (Waldau 2001, p. 153), his analysis is based almost exclusively on Pali language sources, largely ignoring the vast collection of primary source material in Sanskrit, let alone Tibetan, Chinese, or other Buddhist languages. Waldau is not the first scholar to assume that the Pali canon somehow speaks for the Buddhist tradition as a whole. There is no doubt that the Pali texts preserve ancient Buddhist teachings, but this antiquity does not grant them authoritative status for all Buddhists. Most Mahāyāna Buddhists (indeed, arguably most Buddhists in general) consider these texts to be of only provisional rather than definitive meaning. It is, therefore, deeply problematic to draw conclusions about the Buddhist tradition as a whole based exclusively or almost exclusively, on Pali texts.

40. For yet another different Buddhist take on animals, see Pu Chengzhong's excellent, but often overlooked, monograph on early Chinese Buddhist perspectives on animals: Pu Chengzhong 2014.

41. Tan's analysis points to the presence of la (bla) - which she translates somewhat problematically as "soul" - as the key factor differentiating humans and animals on the one side from other aspects of the natural world on the other. These nomads, therefore, frame the kinship between humans and animals using different terms than the elite religious scholars I have analysed here. The implications of this different language are intriguing and deserve further study, but for the present it is sufficient to note that the result is similar: humans and animals are akin to each other, and distinct from rocks, trees, and so on.

\section{ABSTRACTS}

Like other Buddhist traditions, Tibetan Buddhism recognizes that because animals are sentient beings they have some level of moral standing, meaning that humans should take animal needs and concerns into account when deciding what to do in any given situation. In this article, 
therefore, I do not seek to determine whether animals have moral standing at all, but rather whether this moral standing is minimal (meaning that animal concerns are far below human concerns) or maximal (animals and humans are equally important). Through an analysis of Tibetan Buddhist textual sources, I argue that while this tradition does place humans above animals, it nonetheless grants animals a relatively high degree of moral status, and as such the impact of human actions on animals needs to be taken seriously.

Comme les autres traditions bouddhiques, le bouddhisme tibétain reconnaît que, parce que les animaux sont des êtres sensibles, ils ont un certain sens moral, ce qui signifie que les humains doivent tenir compte de leurs besoins et de leurs préoccupations pour décider de ce qu'il faut faire dans une situation donnée. Dans cet article, je ne cherche pas à déterminer si les animaux ont un sens moral, mais plutôt si ce sens moral est minimal (ce qui signifie que les préoccupations des animaux sont bien en-deçà des préoccupations humaines) ou maximal (animaux et humains ont une égale importance). À travers une analyse des sources textuelles bouddhiques tibétaines, je soutiens que si cette tradition place les humains au-dessus des animaux, elle confère néanmoins à ces derniers un statut moral relativement élevé et, par conséquent, l'impact des actions humaines sur les animaux doit être pris au sérieux.

\section{INDEX}

Mots-clés: animaux, Tibet, bouddhisme, végétarisme, éthique

Keywords: animals, Tibet, Buddhism, vegetarianism, ethics

\section{AUTHOR}

\section{GEOFFREY BARSTOW}

Geoffrey Barstow received his PhD from the University of Virginia in 2013. He is now an assistant professor of Religious Studies at Oregon State University, with a research focus on the history and practice of vegetarianism in Tibetan Buddhism. His book on this topic, Food of Sinful Demons. Meat, Vegetarianism, and the Limits of Buddhism in Tibet, was published in 2018 by Columbia University Press.

barstowg@oregonstate.edu 